Article

\title{
Strength Performance and Microstructure of Calcium Sulfoaluminate Cement-Stabilized Soft Soil
}

\author{
Hailong Liu ${ }^{1,2} \mathbb{D}$, Jiuye Zhao ${ }^{1}$, Yu Wang ${ }^{1}$, Nangai Yi ${ }^{1, *}$ and Chunyi Cui ${ }^{1}$ \\ 1 Department of Civil Engineering, Dalian Maritime University, Dalian 116026, China; \\ liuhailong@dlmu.edu.cn (H.L.); zhaojiuye@dlmu.edu.cn (J.Z.); wangyu2018@dlmu.edu.cn (Y.W.); \\ cuichunyi@dlmu.edu.cn (C.C.) \\ 2 MOE Key Laboratory of Soft Soils and Geoenvironmental Engineering, Zhejiang University, \\ Hangzhou 310058, China \\ * Correspondence: yinangai@dlmu.edu.cn
}

Citation: Liu, H.; Zhao, J.; Wang, Y.; Yi, N.; Cui, C. Strength Performance and Microstructure of Calcium Sulfoaluminate Cement-Stabilized Soft Soil. Sustainability 2021, 13, 2295. https://doi.org/10.3390/su13042295

Academic Editor: Slobodan

B. Mickovski

Received: 31 January 2021

Accepted: 17 February 2021

Published: 20 February 2021

Publisher's Note: MDPI stays neutral with regard to jurisdictional claims in published maps and institutional affiliations.

Copyright: (c) 2021 by the authors. Licensee MDPI, Basel, Switzerland. This article is an open access article distributed under the terms and conditions of the Creative Commons Attribution (CC BY) license (https:// creativecommons.org/licenses/by/ $4.0 /)$.

\begin{abstract}
Calcium sulfoaluminate cement (CSA) was used to stabilize a type of marine soft soil in Dalian China. Unconfined compressive strength (UCS) of CSA-stabilized soil was tested and compared to ordinary Portland cement (OPC); meanwhile the influence of amounts of gypsum in CSA and cement contents in stabilized soils on the strength of stabilized soils were investigated. $\mathrm{X}$-ray diffraction (XRD) tests were employed to detect generated hydration products, and scanning electron microscopy (SEM) was conducted to analyze microstructures of CSA-stabilized soils. The results showed that UCS of CSA-stabilized soils at 1, 3, and $28 \mathrm{~d}$ firstly increased and then decreased with contents of gypsum increasing from 0 to $40 \mathrm{wt} . \%$, and CSA-stabilized soils exhibited the highest UCS when the content of gypsum equaled $25 \mathrm{wt} . \%$. When the mixing amounts of OPC and CSA were the same, CSA-stabilized soils had a significantly higher early strength ( 1 and $3 \mathrm{~d}$ ) than OPC. For CSA-stabilized soil with $0 \mathrm{wt}$.\% gypsum, monosulfate (AFm) was detected as a major hydration product. As for CSA-stabilized soil with certain amounts of gypsum, the intensity of ettringite (Aft) was significantly higher than that in the sample hydrating without gypsum, but a tiny peak of AFm also could be detected in the sample with $15 \mathrm{wt} . \%$ gypsum at $28 \mathrm{~d}$. Additionally, the intensity of AFt increased with the contents of gypsum increasing from 0 to $25 \mathrm{wt}$.\%. When contents of gypsum increased from 25 to $40 \mathrm{wt}$.\%, the intensity of AFt tended to decrease slightly, and residual gypsum could be detected in the sample with $40 \mathrm{wt}$.\% gypsum at $28 \mathrm{~d}$. In the microstructure of OPC-stabilized soils, hexagonal plate-shaped calcium hydroxide $(\mathrm{CH})$ constituted skeleton structures, and clusters of hydrated calcium silicates (C-S-H) gel adhered to particles of soils. In the microstructure of CSAstabilized soils, AFt constituted skeleton structures, and the crystalline sizes of ettringite increased with contents of gypsum increasing; meanwhile, clusters of the aluminum hydroxide $\left(\mathrm{AH}_{3}\right)$ phase could be observed to adhere to particles of soils and strengthen the interaction.
\end{abstract}

Keywords: calcium sulfoaluminate cement; stabilized soil; unconfined compressive strength; hydration products; microstructure; sustainability

\section{Introduction}

Soft soil deposits exist all over the planet, such as in the economically developed areas located on the southeast coast of China. Land resources are becoming increasingly scarce with the development and expansion of these cities. As a result, a large number of structures need to be built on soft soil foundations. Soft soil is often a challenge for engineers due to the mechanical properties of poor bearing capacity, low shear strength, and high compressibility [1-5]. To improve the engineering performance of soft soils, a series of methods including cement-based stabilization, alkali-activated treatment, and carbonation techniques are conducted in geotechnical engineering [6-11]. Studies have indicated that cementation can alter the characteristics of soil behaviors and significantly improve the strength properties of soft soil. For example, artificial cementation has been applied for 
soil stabilization, for column-type reinforcement in soft soils, in gravity composite structures, for liquefaction mitigation, and as in-place barriers for cutting off seepage [12-14]. Cement-based stabilization is the most common method for enhancing the performance of soft soils used in construction projects, in which ordinary Portland cement (OPC) is always chosen as the binder owing to its easy availability, and extensive literature is available for reference [15-19]. OPC-treated soil has improved bearing capacity and reduced permeability and compressibility [20,21]. For OPC-stabilized soft soils, the strength mainly originates from hydration reactions of minerals in OPC; furthermore, hydrated calcium silicates (abbreviated as $\mathrm{C}-\mathrm{S}-\mathrm{H}$, in this paper cement abbreviation has been used as followed $\mathrm{C}: \mathrm{CaO}, \mathrm{S}$ : $\left.\mathrm{SiO}_{2}, \mathrm{~A}: \mathrm{Al}_{2} \mathrm{O}_{3}, \$: \mathrm{SO}_{3}, \mathrm{H}: \mathrm{H}_{2} \mathrm{O}\right)$ and calcium hydroxide $\left(\mathrm{Ca}(\mathrm{OH})_{2}\right.$, abbreviated as $\left.\mathrm{CH}\right)$ are the main hydration products $[1,22]$. Besides, it should be noted that potential pozzolanic reactions between calcium hydroxide and alkali active admixtures also contribute to the strength of OPC-based stabilization in the long term [23].

However, OPC also exhibited a limitation of engineering performance in several aspects, such as relatively low strength development, and inclined erosion of hardened pastes $[24,25]$. On the other hand, OPC poses significant environmental concerns associated with carbon dioxide $\left(\mathrm{CO}_{2}\right)$ emissions released during its manufacturing process. With the annually increased consumption of OPC, there is a strong need for sustainable development [26-28]. To improve the performance of cement-based materials and reduce $\mathrm{CO}_{2}$ emissions, special types of cement were applied as an alternative to OPC in certain situations, in which calcium sulfoaluminate (CSA) cement has attracted attention [29-32]. CSA has characters of rapid hardening, high early strength, resistance to sulfate attack, and tailored expansion [33]. The main components of CSA are ye'elimite $\left(\mathrm{C}_{4} \mathrm{~A}_{3} \$\right)$, belite $\left(\mathrm{C}_{2} \mathrm{~S}\right)$ and gypsum $\left(\mathrm{C} \$ \cdot \mathrm{H}_{2}\right)$, and the main hydration of CSA at an early stage is the reaction between $\mathrm{C}_{4} \mathrm{~A}_{3} \$$ and $\mathrm{C} \$ \cdot \mathrm{H}_{2}[30,34,35]$.

In previous studies related to CSA cement-based stabilization, Gastaldi et al. [36] studied the hydration of CSA cement with different contents of sulfate and silicate. Vinoth et al. [37] investigated the early strength development of two types of CSA cement using ultrasonic pulse velocity and measuring unconfined compressive strength. Li and Chang [38] examined the effects of $\mathrm{C} \$ \cdot \mathrm{H}_{2}$ on the CSA hydration system investigating the mechanical properties, hydration process, and hydration mechanism. Lan and Glasser [39] investigated CSA cement hydration by studying scanning electron microscope images and isothermal calorimetry of CSA cements, simulating various clinker mineralogies including lime, $\mathrm{C} \$ \cdot \mathrm{H}_{2}$, $\mathrm{C}_{2} \mathrm{~S}$, and CSA. Tang et al. [40] investigated the hydration stages and phase transformation between ettringite and monosulfate of CSA cement. Winnefeld and Lothenbach [27] studied the hydration of CSA with different water-to-cement ratios.

However, the use of CSA cement in geotechnical applications has been explored in a limited way as yet. Furthermore, soil structure is different from that of cement paste; hence the experience gained from cement paste cannot be applied directly in soft soil stabilization $[13,28,41]$. In this paper, CSA was used to stabilize a type of marine soft soil in Dalian China. The strength of CSA-stabilized soil was tested and compared to that of OPC; meanwhile, the influence of amounts of $\mathrm{C} \$ \cdot \mathrm{H}_{2}$ in CSA and cement content in stabilized soils on the strength of stabilized soils were investigated. X-ray diffraction (XRD) tests were employed to detect generated hydration products; meanwhile, a scanning electron microscope (SEM) was used to analyze microstructures of CSA-stabilized soils.

\section{Materials and Methods}

\subsection{Raw Materials of the Experiments}

In this manuscript, soft soil was collected from a coastal region in Dalian, a city in northeast China. OPC and CSA clinker were commercial products and purchased from Xiaoyetian Cement Company and Beijixiong Cement Company, respectively. $\mathrm{C} \$ \cdot \mathrm{H}_{2}$ was an analytic reagent. Chemical compositions and particle size distributions of raw materials are respectively shown in Table 1 and Figure 1. 
Table 1. Chemical composition of raw materials (wt.\%).

\begin{tabular}{ccccccccccc}
\hline Raw Materials & $\mathbf{C a O}$ & $\mathbf{F e}_{\mathbf{2}} \mathbf{O}_{\mathbf{3}}$ & $\mathbf{M g O}$ & $\mathbf{A l}_{\mathbf{2}} \mathbf{O}_{3}$ & $\mathbf{S i O}_{\mathbf{2}}$ & $\mathbf{S O}_{\mathbf{3}}$ & $\mathbf{N a}_{\mathbf{2}} \mathbf{O}$ & $\mathbf{K}_{\mathbf{2}} \mathbf{O}$ & $\mathrm{TiO}_{\mathbf{2}}$ & $\mathbf{O t h e r s}$ \\
\hline Soft soil & 5.55 & 8.65 & 6.41 & 22.48 & 43.88 & 0.83 & 3.42 & 5.77 & 2.19 & 0.82 \\
OPC & 73.74 & 3.42 & 3.50 & 5.82 & 9.15 & 1.86 & 0.29 & 0.90 & 0.88 & 0.44 \\
CSA clinker & 53.95 & 2.23 & 2.60 & 29.04 & 3.28 & 4.85 & 0.13 & 0.75 & 2.93 & 0.24 \\
Gypsum & 41.18 & - & - & - & - & 58.82 & - & - & - & - \\
\hline
\end{tabular}

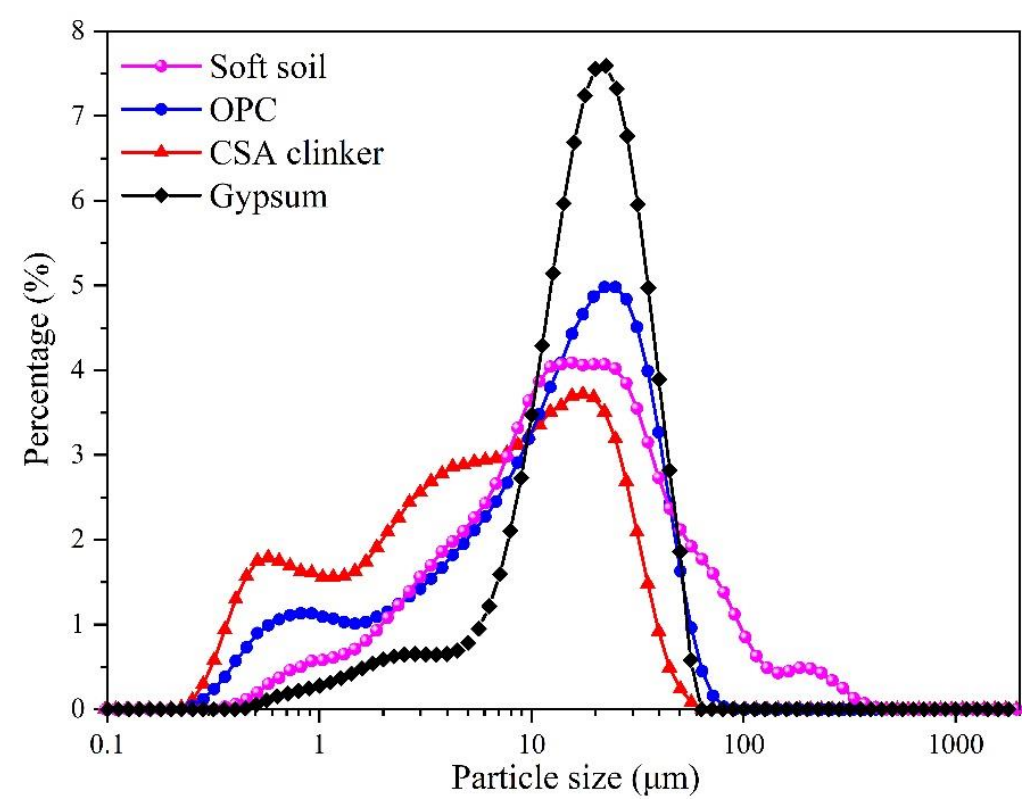

Figure 1. Particle size distribution of raw materials.

\subsection{Specimen Preparation}

Collected soft soils were firstly dried in an oven at $100{ }^{\circ} \mathrm{C}$ for $24 \mathrm{~h}$ and sieved through passing a sieve with $2 \mathrm{~mm}$ mesh. Afterward, dried and sieved soils were mixed with distilled water to prepare wet soils with a water content of $41 \%$, which was closed to the natural moisture content of the soft soils. CSA clinker and different amounts of $\mathrm{C} \$ \cdot \mathrm{H}_{2}$ were mixed to prepare CSA, and $\mathrm{C} \$ \cdot \mathrm{H}_{2}$ respectively accounted for $0,5,10,15,20,25,30$, 35 , and $40 \mathrm{wt} . \%$ in CSA. For both OPC and CSA, grouts with a binder ratio of 0.5 were prepared, and then adequately mixed with the wet soils. The procedure above simulated treating processes in practical engineering to the maximum extent. After mixing, pastes were poured into a cylindrical mold measuring $\varphi 5 \times H 10 \mathrm{~cm}$ and cured with sealed plastic wraps in a chamber under conditions of $20 \pm 2{ }^{\circ} \mathrm{C}$ and more than $95 \%$ relative humidity.

\subsection{Methods of Tests}

After curing for 1, 3, and $28 \mathrm{~d}$, specimens of stabilized soils were tested for unconfined compressive strength (UCS) according to ASTMD-2166 (American Society of Testing Materials). The rate of loading was controlled to be $1.00 \mathrm{~mm} / \mathrm{min}$. For each UCS test, six specimens were tested to obtain the average value and standard deviation.

At curing ages of 1,3 , and $28 \mathrm{~d}$, a certain amount of crashed hardened paste of stabilized soil was immersed in isopropanol to remove free water and terminate hydration. After immersing for $24 \mathrm{~h}$, the hardened pastes of stabilized soils were dried at $35^{\circ} \mathrm{C}$ and ground to pass a sieve with $45 \mu \mathrm{m}$ mesh. XRD was conducted on a Bruker D8 advance Davinci design X-ray diffractometer $\left(\mathrm{CuK} \alpha_{1,2}\right.$ radiation, $\left.\lambda_{1}=0.15406 \mathrm{~nm}, \lambda_{2}=0.15444 \mathrm{~nm}\right)$ to test the ground pastes of stabilized soils. The operating voltage and current were $40 \mathrm{kV}$ and $40 \mathrm{~mA}$, respectively. Patterns of XRD were collected from 5 to $120^{\circ}(2 \theta)$ with a $0.02^{\circ}$ step size, and each step time equaled $0.1 \mathrm{~s}$. To determine the phases in pastes of 
stabilized soils, Evolution (Bruker) software was used to analyze obtained patterns with the crystallographic database of ICDD-PDF 2019.

To characterize the microstructures of stabilized soils, the scanning electron microscopy (SEM) test was performed on a field emission scanning electron microscope (Zeiss $\Sigma$ IGMA HD type) with an accelerating voltage of $3 / 5 \mathrm{kV}$ to examine crushed pieces of hardened paste.

\section{Results and Discussion}

\subsection{UCS of CSA-Stabilized Soil}

Gypsum is a significant part of CSA cement, and there is an optimal content of $\mathrm{C} \$ \cdot \mathrm{H}_{2}$ in CSA cement for mortar or concrete of CSA cement. To investigate the influence of contents of $\mathrm{C} \$ \cdot \mathrm{H}_{2}$ on CSA-stabilized soils, the UCS of CSA-stabilized soils with different $\mathrm{C} \$ \cdot \mathrm{H}_{2}$ contents were compared in Figure 2 (for both CSA and OPC-stabilized soils in Figure 2, the ratio of cement to dry soils equaled 0.12 ).

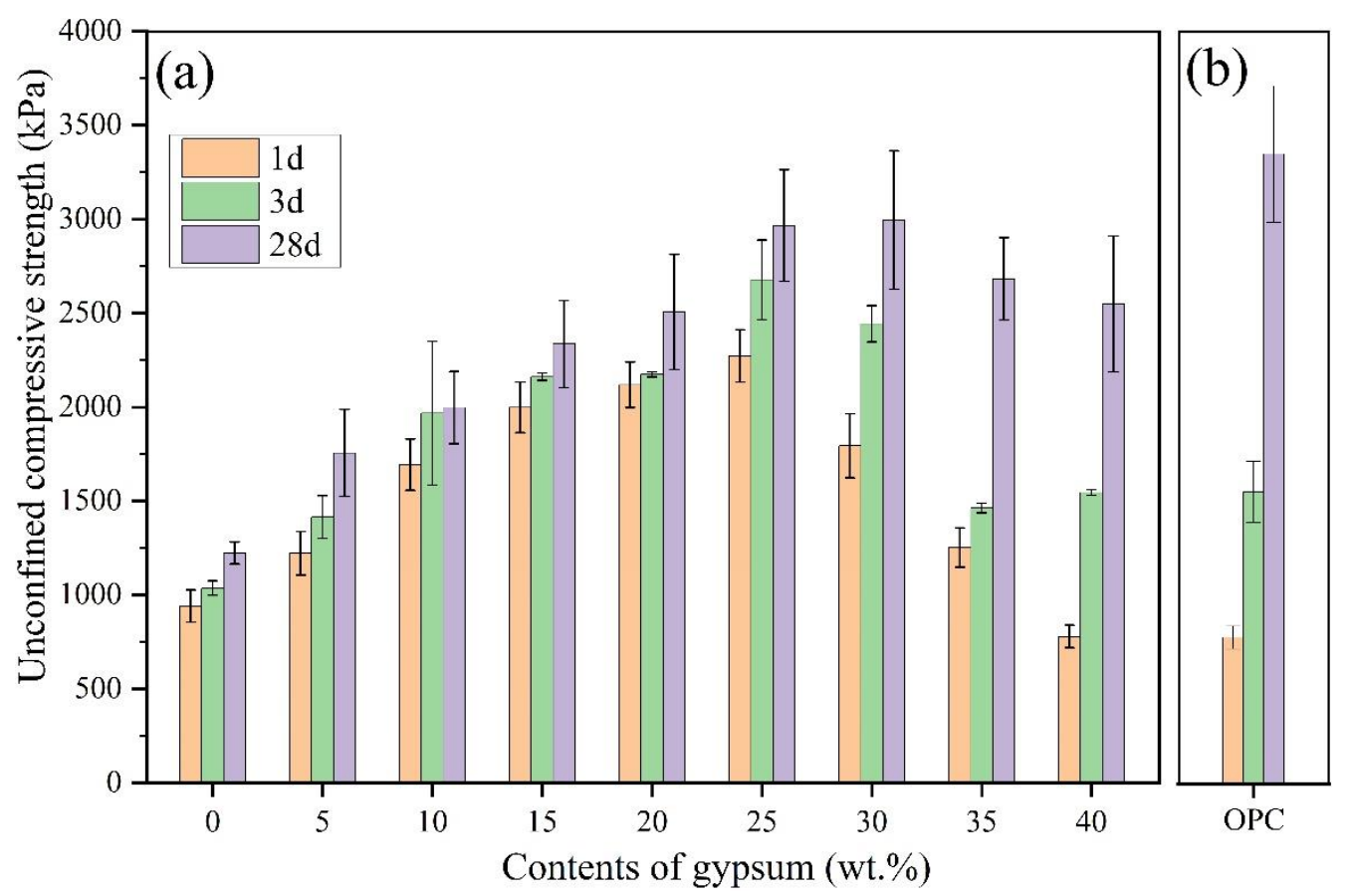

Figure 2. Influence of contents of gypsum on calcium sulfoaluminate cement (CSA)-stabilized soils: (a) unconfined compressive strength (UCS) of CSA-stabilized soils with different gypsum contents, (b) UCS of ordinary Portland cement (OPC)-stabilized soils.

As Figure 2 shows, for CSA-stabilized soils, UCS of CSA-stabilized soils at 1, 3, and $28 \mathrm{~d}$ firstly increased and then decreased with contents of $\mathrm{C} \$ \cdot \mathrm{H}_{2}$ increasing from 0 to $40 \mathrm{wt} . \%$, and CSA-stabilized soils exhibited the highest UCS when contents of $\mathrm{C} \$ \cdot \mathrm{H}_{2}$ equaled $25 \mathrm{wt} . \%$. It should also be noted that when contents of $\mathrm{C} \$ \cdot \mathrm{H}_{2}$ varied from 0 to $25 \mathrm{wt} . \%$, early strength ( 1 and $3 \mathrm{~d}$ ) of CSA-stabilized soils generally exceeded $60 \%$ of the strength at $28 \mathrm{~d}$. However, when contents of $\mathrm{C} \$ \cdot \mathrm{H}_{2}$ were more than $25 \mathrm{wt} . \%$, early strength of CSA-stabilized soils significantly decreased. In terms of early strength, the UCS of CSA-stabilized soils with optimal content of $\mathrm{C} \$ \cdot \mathrm{H}_{2}(25 \mathrm{wt} . \%)$ was more than twice that of OPC-stabilized soils. However, for strength at $28 \mathrm{~d}$, the UCS of OPC-stabilized soils was higher than that of all CSA-stabilized soils. Even UCS of CSA-stabilized soils with optimal content of $\mathrm{C} \$ \cdot \mathrm{H}_{2}$ (the optimal content of $\mathrm{C} \$ \cdot \mathrm{H}_{2}$ for the CSA-stabilized soils was $25 \mathrm{wt} . \%$, with the maximum UCS being $2966 \mathrm{kPa}$ ) was slightly less than that of OPC-stabilized soils $(\mathrm{USC}=3348 \mathrm{kPa})$. To further investigate the influence of mixing amounts of cement on stabilized soils, the UCS of OPC and CSA-stabilized soils are compared in Figure 3. 

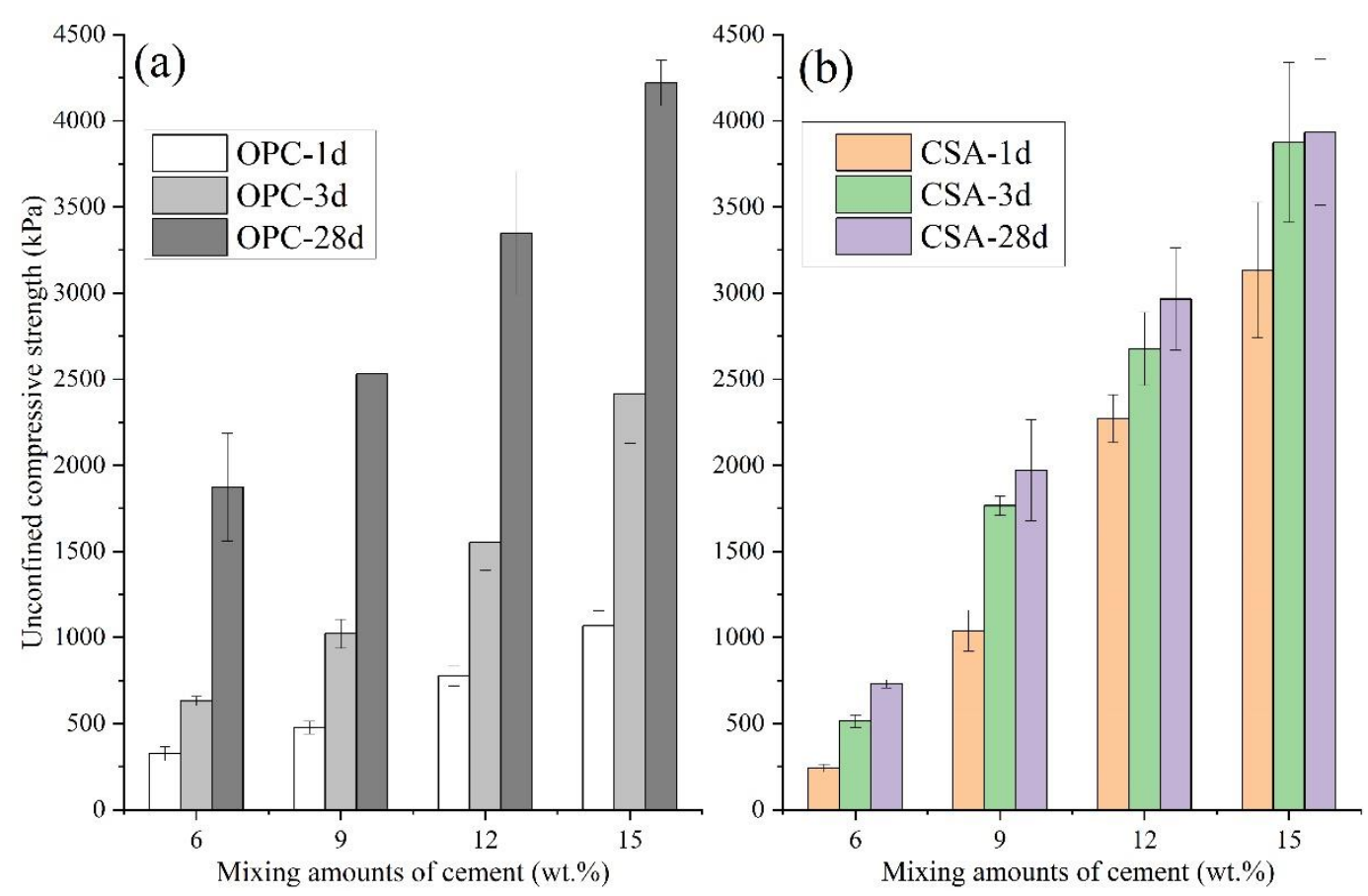

Figure 3. Influence of mixing amounts for different types of cement on UCS of stabilized soils.

As shown in Figure 3, for both CSA and OPC-stabilized soils, UCS at 1, 3, and $28 \mathrm{~d}$ gradually increased with mixing amounts of cement increasing from 6 to $15 \mathrm{wt} . \%$. Meanwhile, it can be also observed that, for stabilized soils with any mixing amounts of OPC, early strength at 1 and $3 \mathrm{~d}$ only achieved approximately $30 \%$ and $50 \%$ strength at $28 \mathrm{~d}$, respectively. On the other hand, for stabilized soils with any mixing amounts of CSA, early strength at 1 and $3 \mathrm{~d}$ was more than the $50 \%$ and $80 \%$ strength at $28 \mathrm{~d}$, respectively. It should be also noted that, when the mixing amounts of OPC and CSA were the same, strength of OPC-stabilized soils at $28 \mathrm{~d}$ was greater than that of CSA, which was more obvious for mixing amounts of 6 and $9 \mathrm{wt} . \%$. The strength development of stabilized soils mainly resulted from continuous hydration of CSA and OPC which prolonged until $28 \mathrm{~d}$; in particular, $\mathrm{C}_{2} \mathrm{~S}$ in both CSA and OPC contributed more to long-term strength.

\subsection{Hydration Products of CSA-Stabilized Soil}

To investigate the hydration products in OPC and CSA-stabilized soils, XRD tests were conducted. For determining the distribution ranges of peaks for hydration products, XRD patterns of OPC and CSA-stabilized soils with 0 and $40 \mathrm{wt} . \% \mathrm{C} \$ \cdot \mathrm{H}_{2}$ at $28 \mathrm{~d}$ were chosen to exhibit in Figure 4 (for all patterns, mixing amounts for different types of cement equaled $12 \mathrm{wt.} \%$ ).

As Figure 4 shows, certain peaks of all three patterns were overlapped and attributed to minerals in the soft soil, such as quartz (major peak at $26.7^{\circ}$ ), muscovite (major peak at $8.9^{\circ}$ ), and potash feldspar (major peak at $27.6^{\circ}$ ). It should be noted that major minerals in the soft soils, including quartz, muscovite, and potash feldspar, are primary minerals with relatively inert activation, which tend to be stable in cement slurries [42,43]. Additionally, the peaks for minerals in the soft soil remained stable during the hydration process of CSA and OPC; thus this paper has not considered chemical interaction between the minerals in the soft soil used in this paper and cement or the hydration products. Meanwhile, certain peaks in the XRD patterns can be attributed to hydration products of OPC or CSA. For OPC-stabilized soil, $\mathrm{CH}$ can be detected as a major crystalline hydration product on account of a peak at $18.1^{\circ}$. The formation of $\mathrm{CH}$ mainly resulted from the hydration of $\mathrm{C}_{3} \mathrm{~S}$ and partial $\mathrm{C}_{2} \mathrm{~S}$. According to the stoichiometry of typical C-S-H found in hydrated $\mathrm{OPC}$, hydration of $\mathrm{C}_{3} \mathrm{~S}$ and $\mathrm{C}_{2} \mathrm{~S}$ can be described by Equation (1) and Equation (2) [44]. As for CSA-stabilized soil, AFt and AFm can be detected as major crystalline hydration 
products due to hydration of $\mathrm{C}_{4} \mathrm{~A}_{3} \$$; meanwhile, residual $\mathrm{C} \$ \cdot \mathrm{H}_{2}$ can also be observed. It can be also noted that the major peaks for $\mathrm{AFt}, \mathrm{AFm}$, and $\mathrm{C} \$ \cdot \mathrm{H}_{2}$ were concentrated in the range of $6-14^{\circ}$. To further investigate the influence of amounts of $\mathrm{C} \$ \cdot \mathrm{H}_{2}$ and hydration age on hydration products in CSA-stabilized soils, XRD patterns in the range of 6-14 of CSA-stabilized soils with different amounts of $\mathrm{C} \$ \cdot \mathrm{H}_{2}$ at different hydration ages were compared in Figure 5.

$$
\begin{aligned}
& \mathrm{C}_{3} \mathrm{~S}+5.3 \mathrm{H} \rightarrow 1.3 \mathrm{CH}+\mathrm{C}_{1.7} \mathrm{SH}_{4} \\
& \mathrm{C}_{2} \mathrm{~S}+4.3 \mathrm{H} \rightarrow 0.3 \mathrm{CH}+\mathrm{C}_{1.7} \mathrm{SH}_{4}
\end{aligned}
$$

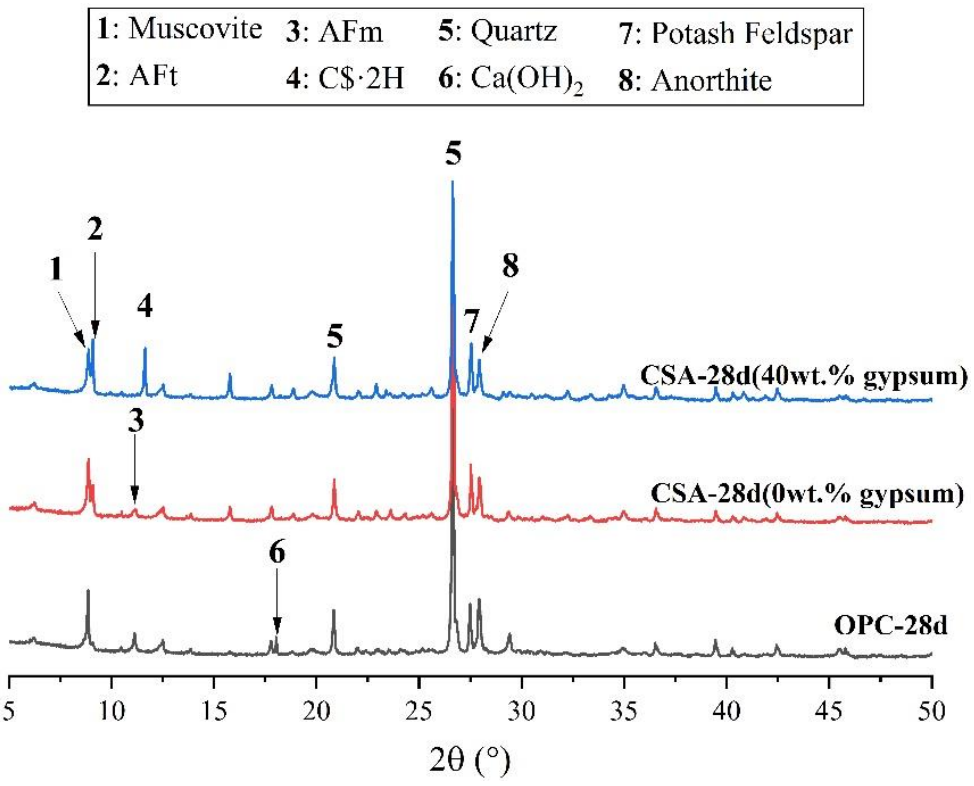

Figure 4. Typical XRD patterns of OPC- and CSA-stabilized soils.

1: Muscovite

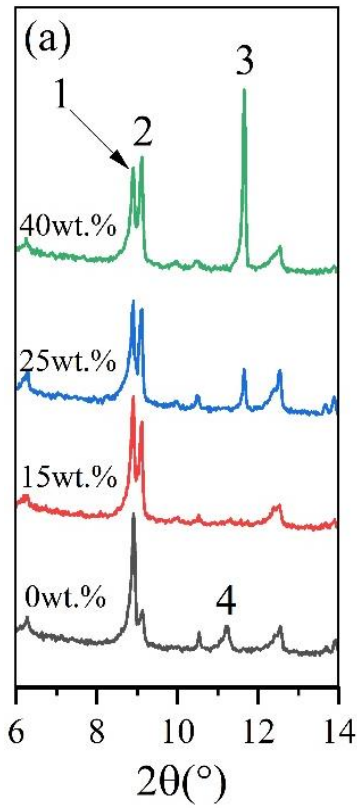

2: $\mathrm{AFt}$

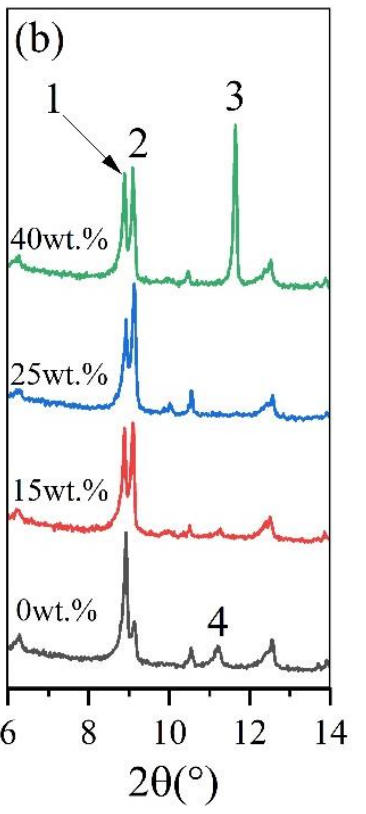

4: AFm

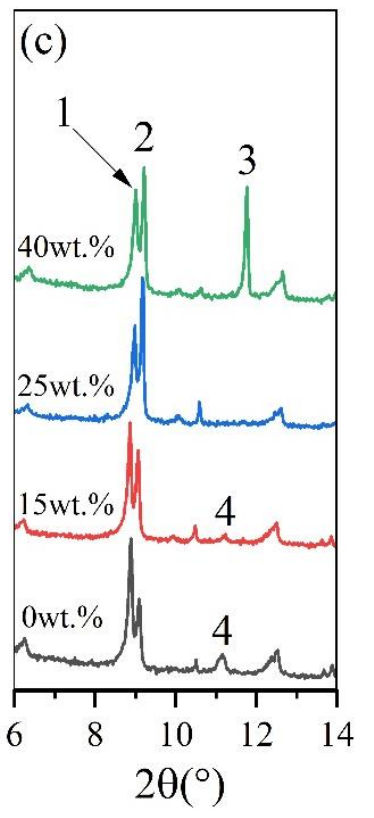

Figure 5. XRD patterns of CSA-stabilized soils with different amounts of gypsum: (a) hydration age of $1 \mathrm{~d}$, (b) hydration age of $3 \mathrm{~d}$, (c) hydration age of $28 \mathrm{~d}$. 
According to the results in Figure 5, it can be seen that for CSA-stabilized soil with 0 wt. $\% \mathrm{C} \$ \cdot \mathrm{H}_{2}$, AFm can be observed, and the formation of AFm can be attributed to hydration of $\mathrm{C}_{4} \mathrm{~A}_{3} \$$ without $\mathrm{C} \$ \cdot \mathrm{H}_{2}$, which can be described by Equation (3). Meanwhile, a relatively low-intensity peak for AFt can be also detected at $9.2^{\circ}$ in the sample without $\mathrm{C} \$ \cdot \mathrm{H}_{2}$. The formation of small quantities of AFt was attributed to the supersaturation of sulfate ions at a very early stage of hydration; additionally, sulfate ions in soft soils can also contribute to the formation of AFt. As for CSA-stabilized soil with certain amounts of $\mathrm{C} \$ \cdot \mathrm{H}_{2}$, it can be observed that the intensity of AFt was significantly higher than that in the samples without $\mathrm{C} \$ \cdot \mathrm{H}_{2}$; meanwhile, a tiny peak of AFm can be detected in the sample with $15 \mathrm{wt} . \% \mathrm{C} \$ \cdot \mathrm{H}_{2}$ at $28 \mathrm{~d}$. Additionally, it also can be noted that the intensity of AFt increased with the contents of $\mathrm{C} \$ \cdot \mathrm{H}_{2}$ increasing from 0 to $25 \mathrm{wt} . \%$. However, when contents of $\mathrm{C} \$ \cdot \mathrm{H}_{2}$ increased from 25 to $40 \mathrm{wt} . \%$, the intensity of AFt tended to decrease slightly, and residual $\mathrm{C} \$ \cdot \mathrm{H}_{2}$ can be detected in the sample with $40 \mathrm{wt} . \% \mathrm{C} \$ \cdot \mathrm{H}_{2}$ at $28 \mathrm{~d}$. Based on the results of previous studies, in the condition of hydrating with $\mathrm{C} \$ \cdot \mathrm{H}_{2}, \mathrm{C}_{4} \mathrm{~A}_{3} \$$ prioritizes to hydrate with $\mathrm{C} \$ \cdot \mathrm{H}_{2}$, and the reaction can be described by Equation (4). After gypsum is thoroughly consumed, $\mathrm{C}_{4} \mathrm{~A}_{3} \$$ continues to react according to Equation (3), which leads to the formation of $\mathrm{AFm}$. Trends of intensity for $\mathrm{AFt}$ and $\mathrm{C} \$ \cdot \mathrm{H}_{2}$ in samples of hydrating with $\mathrm{C} \$ \cdot \mathrm{H}_{2}$ illustrates that for the sample with $15 \mathrm{wt} . \%$ gypsum, both reactions of Equation (3) and Equation (4) occurred during $28 \mathrm{~d}$ hydrating age. As for the sample with $25 \mathrm{wt} . \%$ $\mathrm{C} \$ \cdot \mathrm{H}_{2}, \mathrm{C} \$ \cdot \mathrm{H}_{2}$ was adequate for the reaction of Equation (4). When the content of $\mathrm{C} \$ \cdot \mathrm{H}_{2}$ equaled $40 \mathrm{wt} . \%$, certain amounts of $\mathrm{C} \$ \cdot \mathrm{H}_{2}$ were residual after the reaction of Equation (4).

$$
\begin{gathered}
\mathrm{C}_{4} \mathrm{~A}_{3} \$+18 \mathrm{H} \rightarrow \mathrm{C}_{4} \mathrm{~A} \$ \mathrm{H}_{12}+2 \mathrm{AH}_{3} \\
\mathrm{C}_{4} \mathrm{~A}_{3} \$+2\left(\mathrm{C} \$ \cdot \mathrm{H}_{2}\right)+34 \mathrm{H} \rightarrow \mathrm{C}_{6} \mathrm{~A}_{3} \mathrm{H}_{32}+2 \mathrm{AH}_{3}
\end{gathered}
$$

\subsection{Distinction of Microstructures between OPC- and CSA-Stabilized Soils}

Figure 6 shows the SEM images of OPC- and CSA-stabilized soils. As shown in Figure 6a, hexagonal plate-shaped $\mathrm{CH}$ and gelatinous C-S-H can be observed in the microstructure for OPC-stabilized soils. Hexagonal plate-shaped $\mathrm{CH}$ constituted skeleton structures, and the size approximately ranged from 1 to $3 \mu \mathrm{m}$. Meanwhile, clusters of C-S-H gel adhered to particles of soils, which strengthened the interaction among soil particles.

As for microstructures of CSA-stabilized soils (see Figure $6 \mathrm{~b}-\mathrm{d}$ ), AFt with characters of needle bar granular and nemaline $\mathrm{AH}_{3}$ can be observed. Differing from the microstructure of OPC-stabilized soils, the needle bar-shaped AFt constituted skeleton structures, and the sizes of ettringite impacted by contents of $\mathrm{C} \$ \cdot \mathrm{H}_{2}$. Specifically, the sizes of ettringite fluctuated around $1 \mu \mathrm{m}$ when the content of $\mathrm{C} \$ \cdot \mathrm{H}_{2}$ equaled $10 \mathrm{wt} . \%$ (see Figure $6 \mathrm{~b}$ ). With a content of $\mathrm{C} \$ \cdot \mathrm{H}_{2}$ increasing to $20 \mathrm{wt} . \%$, sizes of ettringite increased to range from around 2 to $3 \mu \mathrm{m}$ (see Figure 6c). As shown in Figure 6d, the largest size of ettringite increased to be more than $4 \mu \mathrm{m}$ when the content of $\mathrm{C} \$ \cdot \mathrm{H}_{2}$ equaled $25 \mathrm{wt} . \%$. Additionally, for CSAstabilized soils with different $\mathrm{C} \$ \cdot \mathrm{H}_{2}$ contents, clusters of $\mathrm{AH}_{3}$ phase could be observed to adhere to particles of soils and strengthen the interaction, which was similar to that of C-S-H gel in OPC-stabilized soils. 

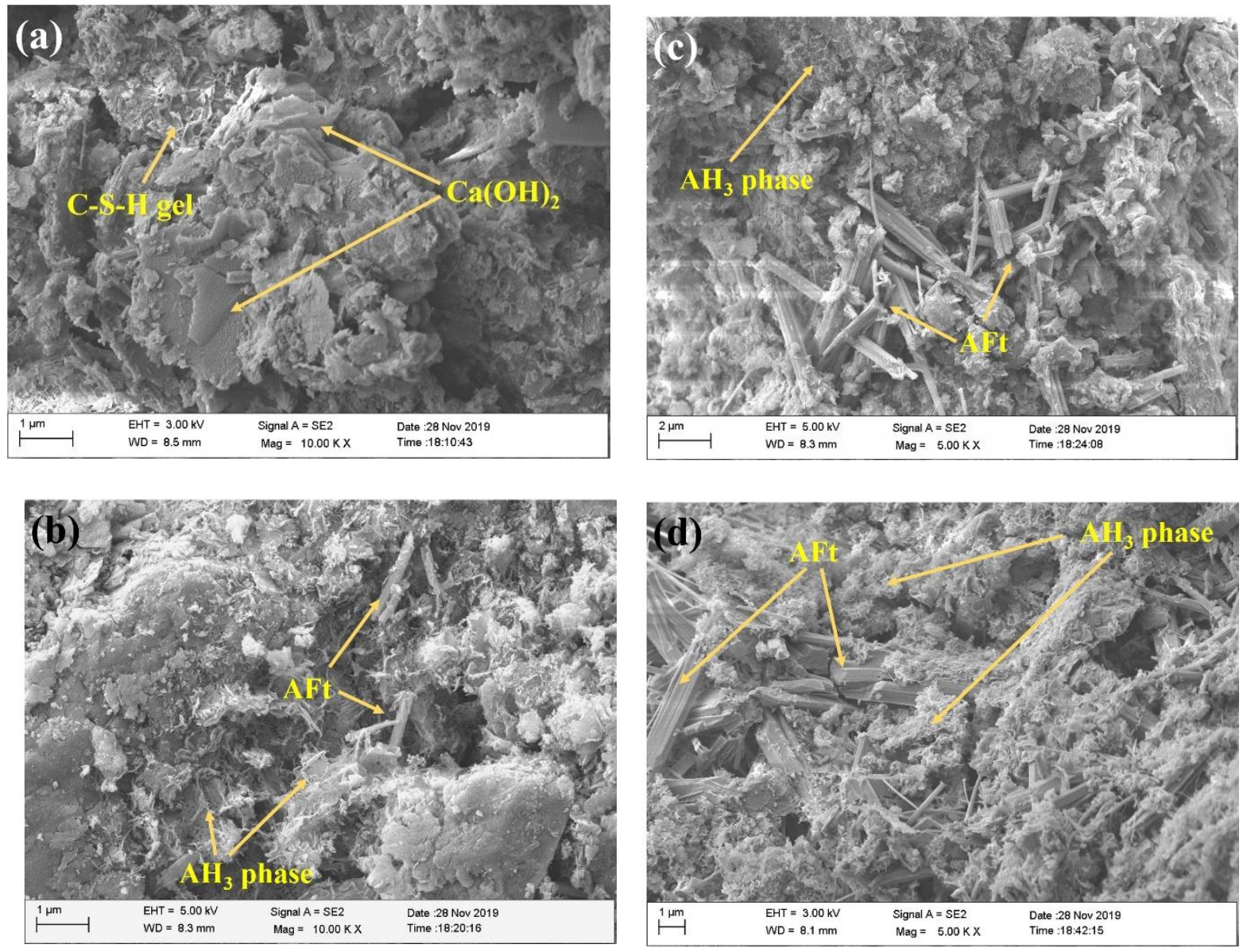

Figure 6. SEM images of OPC- and CSA-stabilized soils: (a) OPC-stabilized soils, (b) CSA-stabilized soils with 10 wt.\% gypsum, (c) CSA-stabilized soils with $20 \mathrm{wt}$ \% gypsum, (d) CSA-stabilized soils with $25 \mathrm{wt}$ \% gypsum.

\section{Conclusions}

Strength performance and microstructure of CSA- and OPC-stabilized soft soils were compared. Based on test results of UCS, XRD, and SEM, the following conclusions can be obtained:

(1) UCS of CSA-stabilized soils at 1, 3, and $28 \mathrm{~d}$ firstly increased and then decreased with contents of $\mathrm{C} \$ \cdot \mathrm{H}_{2}$ increasing from 0 to $40 \mathrm{wt} . \%$. The optimum $\mathrm{C} \$ \cdot \mathrm{H}_{2}$ content for CSA-stabilized soils was $25 \mathrm{wt} . \%$, which means the stabilized soils had the highest UCS. When the mixing amounts of OPC and CSA were the same, CSA-stabilized soils had significantly higher early strength $(1$ and $3 \mathrm{~d})$ than OPC and similar strength at $28 \mathrm{~d}$.

(2) For CSA-stabilized soil with 0 wt. $\% \mathrm{C} \$ \cdot \mathrm{H}_{2}, \mathrm{AFm}$ was detected as a major hydration product. As for CSA-stabilized soil with certain amounts of $\mathrm{C} \$ \cdot \mathrm{H}_{2}$, the intensity of AFt was significantly higher than that in the sample hydrating without $\mathrm{C} \$ \cdot \mathrm{H}_{2} ;$ meanwhile, a tiny peak of AFm could be also detected in the sample with $15 \mathrm{wt} . \% \mathrm{C} \$ \mathrm{H}_{2}$ at $28 \mathrm{~d}$. Additionally, the intensity of AFt increased with the contents of gypsum increasing from 0 to $25 \mathrm{wt} . \%$. When contents of $\mathrm{C} \$ \cdot \mathrm{H}_{2}$ increased from 25 to $40 \mathrm{wt} . \%$, the intensity of AFt tended to decrease slightly, and residual $\mathrm{C} \$ \cdot \mathrm{H}_{2}$ could be detected in the sample with 40 wt. $\% \mathrm{C} \$ \cdot \mathrm{H}_{2}$ at $28 \mathrm{~d}$.

(3) In the microstructure of OPC-stabilized soils, hexagonal plate-shaped $\mathrm{CH}$ constituted skeleton structures, and clusters of C-S-H gel adhered to particles of soils. In the microstructure of CSA-stabilized soils, AFt constituted skeleton structures, and the crystalline sizes of ettringite increased with contents of $\mathrm{C} \$ \cdot \mathrm{H}_{2}$ increasing, meanwhile, 
clusters of $\mathrm{AH}_{3}$ phase could be observed to adhere to particles of soils and strengthen the interaction.

\begin{abstract}
Author Contributions: Conceptualization, H.L. and C.C.; methodology, H.L.; software, N.Y. and J.Z.; validation, J.Z., Y.W. and C.C.; formal analysis, J.Z.; investigation, N.Y. and Y.W.; resources, N.Y.; data curation, J.Z. and Y.W.; writing-original draft preparation, H.L.; writing-review and editing, J.Z. and C.C.; visualization, N.Y. and H.L.; supervision, H.L.; project administration, H.L. and C.C.; funding acquisition, H.L. All authors have read and agreed to the published version of the manuscript.
\end{abstract}

Funding: This research was funded by the National Natural Science Foundation of China (NSFC), grant number 52008071; the Natural Science Foundation of Liaoning Province, grant number 2019ZD0150; Key Laboratory of Soft Soils and Geoenvironmental Engineering (Zhejiang University), Ministry of Education, grant number 2019P01; Key Laboratory of Ministry of Education for Geomechanics and Embankment Engineering, Hohai University, grant number 201802, and the United Navigation Foundation of Liaoning Province, grant number 2020-HYLH-48.

Institutional Review Board Statement: Not applicable.

Informed Consent Statement: Not applicable.

Data Availability Statement: Data sharing is not applicable to this article.

Conflicts of Interest: The authors declare that they have no conflict of interest.

\title{
References
}

1. Ekinci, A. Effect of preparation methods on strength and microstructural properties of cemented marine clay. Constr. Build. Mater. 2019, 227, 116690. [CrossRef]

2. Kang, G.; Tsuchida, T.; Kim, Y. Strength and stiffness of cement-treated marine dredged clay at various curing stages. Constr. Build. Mater. 2017, 132, 71-84. [CrossRef]

3. Kun, M.; Chunyi, C.; Haijiang, L. An Ontology Framework for Pile Integrity Evaluation Based on Analytical Methodology. IEEE Access 2020, 99, 72158-72168.

4. Yi, Y.; Li, C.; Liu, S.; Al-Tabbaa, A. Resistance of MgO-GGBS and CS-GGBS stabilised marine soft clays to sodium sulfate attack. Géotechnique 2014, 64, 673-679. [CrossRef]

5. Ho, T.O.; Chen, W.B.; Yin, J.H.; Wu, P.C.; Tsang, D.C. Stress-Strain behaviour of Cement-Stabilized Hong Kong marine deposits. Constr. Build. Mater. 2021, 274, 122103. [CrossRef]

6. Mickovski, S.B.; Stokes, A.; Van Beek, R.; Ghestem, M.; Fourcaud, T. Simulation of direct shear tests on rooted and non-rooted soil using finite element analysis. Ecol. Eng. 2011, 37, 1523-1532. [CrossRef]

7. Lang, L.; Liu, N.; Chen, B. Strength development of solidified dredged sludge containing humic acid with cement, lime and nano-SiO ${ }_{2}$. Constr. Build. Mater. 2020, 230, 116971. [CrossRef]

8. Jamshidi, R.J.; Lake, C.B. Hydraulic and strength properties of unexposed and freeze-thaw exposed cement-stabilized soils. Can. Geotech. J. 2015, 52, 283-294. [CrossRef]

9. Yi, Y.; Gu, L.; Liu, S.; Puppala, A.J. Carbide slag-activated ground granulated blastfurnace slag for soft clay stabilization. Can. Geotech. J. 2015, 52, 656-663. [CrossRef]

10. Robayo, R.A.; Mulford, A.; Munera, J.; de Gutiérrez, R.M. Alternative cements based on alkali-activated red clay brick waste. Constr. Build. Mater. 2016, 128, 163-169. [CrossRef]

11. Cui, C.; Meng, K.; Xu, C.; Liang, Z.; Li, H.; Pei, H. Analytical solution for longitudinal vibration of a floating pile in saturated porous media based on a fictitious saturated soil pile model. Comput. Geotech. 2021, 131, 103942. [CrossRef]

12. Yi, Y.; Li, C.; Liu, S. Alkali-Activated Ground-Granulated Blast Furnace Slag for Stabilization of Marine Soft Clay. J. Mater. Civil Eng. 2015, 27, 04014146. [CrossRef]

13. Subramanian, S.; Moon, S.W.; Moon, J.; Ku, T. CSA-treated sand for geotechnical application: Microstructure analysis and rapid strength development. J. Mater. Civil Eng. 2018, 30, 04018313. [CrossRef]

14. Kim, G.M.; Jang, J.G.; Khalid, H.R.; Lee, H.K. Water purification characteristics of pervious concrete fabricated with CSA cement and bottom ash aggregates. Constr. Build. Mater. 2017, 136, 1-8. [CrossRef]

15. Ghadir, P.; Ranjbar, N. Clayey soil stabilization using geopolymer and Portland cement. Constr. Build. Mater. 2018, 188, 361-371. [CrossRef]

16. Uchima, J.S.; Restrepo-Baena, O.J.; Tobón, J.I. Mineralogical evolution of portland cement blended with metakaolin obtained in simultaneous calcination of kaolinitic clay and rice husk. Constr. Build. Mater. 2016, 118, 286-293. [CrossRef]

17. Behnood, A. Soil and clay stabilization with calcium- and non-calcium-based additives: A state-of-the-art review of challenges, approaches and techniques. Transp. Geotech. 2018, 17, 14-32. [CrossRef] 
18. Muvuna, J.; Boutaleb, T.; Mickovski, S.B.; Baker, K.; Mohammad, G.S.; Cools, M.; Selmi, W. Information integration in a smart city system-A case study on air pollution removal by green infrastructure through a vehicle smart routing system. Sustainability 2020, 12, 5099. [CrossRef]

19. Yoon, H.N.; Seo, J.; Kim, S.; Lee, H.K.; Park, S. Hydration of calcium sulfoaluminate cement blended with blast-furnace slag. Constr. Build. Mater. 2021, 268, 121214. [CrossRef]

20. Horpibulsuk, S.; Rachan, R.; Chinkulkijniwat, A.; Raksachon, Y.; Suddeepong, A. Analysis of strength development in cementstabilized silty clay from microstructural considerations. Constr. Build. Mater. 2010, 24, 2011-2021. [CrossRef]

21. Lorenzo, G.A.; Bergado, D.T. Fundamental parameters of cement-admixed clay-New approach. J. Geotech. Geoenvir. Eng. 2004, 130, 1042-1050. [CrossRef]

22. Wu, J.; Deng, Y.; Zheng, X.; Cui, Y.; Zhao, Z.; Chen, Y.; Zha, F. Hydraulic conductivity and strength of foamed cement-stabilized marine clay. Constr. Build. Mater. 2019, 222, 688-698. [CrossRef]

23. Liu, L.; Zhou, A.; Deng, Y.; Cui, Y.; Yu, Z.; Yu, C. Strength performance of cement/slag-based stabilized soft clays. Constr. Build. Mater. 2019, 211, 909-918. [CrossRef]

24. Shi, C.; Jiménez, A.F.; Palomo, A. New cements for the 21st century: The pursuit of an alternative to Portland cement. Cem. Concr. Res. 2011, 41, 750-763. [CrossRef]

25. Zhou, Q.; Milestone, N.B.; Hayes, M. An alternative to Portland Cement for waste encapsulation-The calcium sulfoaluminate cement system. J. Hazard. Mater. 2006, 136, 120-129. [CrossRef]

26. Muvuna, J.; Boutaleb, T.; Baker, K.J.; Mickovski, S.B. A methodology to model integrated smart city system from the information perspective. Smart Cities 2019, 2, 496-511. [CrossRef]

27. Winnefeld, F.; Lothenbach, B. Hydration of calcium sulfoaluminate cements-Experimental findings and thermodynamic modelling. Cement Concr. Res. 2010, 40, 1239-1247. [CrossRef]

28. Seo, J.; Kim, S.; Park, S.; Yoon, H.N.; Lee, H.K. Carbonation of calcium sulfoaluminate cement blended with blast furnace slag. Cement Concr. Compos. 2021, 118, 103918. [CrossRef]

29. Le Saoût, G.; Lothenbach, B.; Hori, A.; Higuchi, T.; Winnefeld, F. Hydration of Portland cement with additions of calcium sulfoaluminates. Cement Concr. Res. 2013, 43, 81-94. [CrossRef]

30. Juenger, M.C.; Winnefeld, F.; Provis, J.L.; Ideker, J.H. Advances in alternative cementitious binders. Cement Concr. Res. 2011, 41, 1232-1243. [CrossRef]

31. Meng, K.; Cui, C.; Liang, Z.; Li, H.; Pei, H. A new approach for longitudinal vibration of a large-diameter floating pipe pile in visco-elastic soil considering the three-dimensional wave effects. Comput. Geotech. 2020, 128, 103840. [CrossRef]

32. Quillin, K. Performance of belite-sulfoaluminate cements. Cement Concr. Res. 2001, 31, 1341-1349. [CrossRef]

33. Guotang, Z.; Wei, S.; Guotao, Y.; Li, P.; Degou, C.; Jinyang, J.; Hao, H. Mechanism of cement on the performance of cement stabilized aggregate for high speed railway roadbed. Constr. Build. Mater. 2017, 144, 347-356. [CrossRef]

34. Michel, M.; Georgin, J.F.; Ambroise, J.; Péra, J. The influence of gypsum ratio on the mechanical performance of slag cement accelerated by calcium sulfoaluminate cement. Constr. Build. Mater. 2011, 25, 1298-1304. [CrossRef]

35. Glasser, F.P.; Zhang, L. High-performance cement matrices based on calcium sulfoaluminate-belite compositions. Cement Concr. Res. 2001, 31, 1881-1886. [CrossRef]

36. Gastaldi, D.; Paul, G.; Marchese, L.; Irico, S.; Boccaleri, E.; Mutke, S.; Buzzi, L.; Canonico, F. Hydration products in sulfoaluminate cements: Evaluation of amorphous phases by XRD/solid-state NMR. Cement Concr. Res. 2016, 90, 162-173. [CrossRef]

37. Vinoth, G.; Moon, S.W.; Moon, J.; Ku, T. Early strength development in cement-treated sand using low-carbon rapid-hardening cements. Soils Found. 2018, 58, 1200-1211. [CrossRef]

38. Li, J.; Chang, J. Effect of crystal/amorphous ratio on mechanical properties in a C4A3 \$-C2S hydration system with or without gypsum addition. Constr. Build. Mater. 2019, 208, 36-45. [CrossRef]

39. Lan, W.; Glasser, F.P. Hydration of calcium sulphoaluminate cements. Adv. Cement Res. 1996, 8, 127-134. [CrossRef]

40. Tang, S.W.; Zhu, H.G.; Li, Z.J.; Chen, E.; Shao, H.Y. Hydration stage identification and phase transformation of calcium sulfoaluminate cement at early age. Constr. Build. Mater. 2015, 75, 11-18. [CrossRef]

41. Subramanian, S.; Khan, Q.; Ku, T. Strength development and prediction of calcium sulfoaluminate treated sand with optimized gypsum for replacing OPC in ground improvement. Constr. Build. Mater. 2019, 202, 308-318. [CrossRef]

42. Rakhimova, N.R. Recent advances in blended alkali-activated cements: A review. Eur. J. Environ. Civil Eng. 2020, 5, 1-23. [CrossRef]

43. Ngole, V.M.; Totolo, O.; Ekosse, G.E. Physico-chemical and mineralogical characterisation of subsurface sediments around Gaborone Landfill, Botswana. J. Appl. Sci. Environ. Manag. 2004, 8, 49-53. [CrossRef]

44. Morin, V.; Termkhajornkit, P.; Huet, B.; Pham, G. Impact of quantity of anhydrite, water to binder ratio, fineness on kinetics and phase assemblage of belite-ye'elimite-ferrite cement. Cem. Concr. Res. 2017, 99, 8-17. [CrossRef] 